\title{
A Systemic Lupus Erythematosus Patient with
} Isolated Neutropenia and Diminished Expression of CD55 and CD59 Similar to Paroxysmal Nocturnal Hemoglobinuria

\author{
Nötropenisi Olan Sistemik Lupus Eritematodesli Bir Hastada \\ Paroksismal Noktürnal Hemoglobinüri'ne Benzer Şekilde \\ Azalmış CD55 ve CD59 İfadelenmesi
}

Abdülkerim Yıldız, Merih Kızıl Çakar, Elif Suyanı, Gülsan Türköz Sucak

Gazi University Faculty of Medicine, Department of Hematology, Ankara, Turkey

To the Editor,

The association of systemic lupus erythematosus (SLE) and paroxysmal nocturnal hemoglobinuria (PNH) has been rarely reported $[1,2]$. However, diminished expression of CD55 and CD59 on red blood cells and lymphocytes has been demonstrated in SLE patients in the absence of PNH $[3,4,5,6]$.

A 30-year-old female with a history of SLE was diagnosed with pulmonary artery embolism after being admitted to the hospital with sudden-onset dyspnea. She was treated with heparin, which was followed by warfarin. She also had a previous history of deep venous thrombosis of the left lower extremity while on oral contraceptives 2 years prior to the diagnosis of SLE. After the diagnosis of SLE, steroids and hydroxychloroquine were begun, which she stopped taking on her own. Blood cell counts revealed neutropenia with a white blood cell count of $2.32 \times 109 / \mathrm{L}$, neutrophil count of $0.94 \times 10^{9} / \mathrm{L}$, lymphocyte count of $0.93 \times 109 / \mathrm{L}$, hemoglobin of $137 \mathrm{~g} / \mathrm{L}$, and platelet count of $254 \times 109 / \mathrm{L}$. Serum biochemistries were within normal limits. Immunological tests revealed positive antinuclear antibodies ( 3 positive, thin granular, spotted) and anti-dsDNA at a level of 587 $\mathrm{IU} / \mathrm{mL}$. Tests for antiphospholipid syndrome including lupus anticoagulants, $\beta 2$-glycoprotein I antibodies, and anticardiolipin and antiphospholipid antibodies were all negative. Genetic mutations for factor $\mathrm{V}$ Leiden and the prothrombin gene were negative. Proteins $C$ and $S$ and
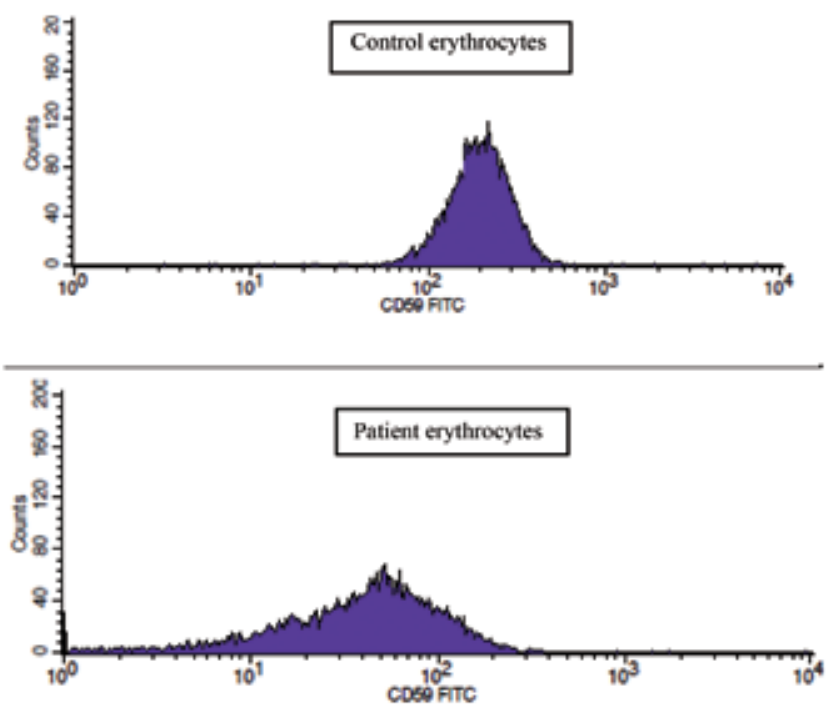

Figure 1a. Diminished expression of CD59 on patient erythrocytes. 

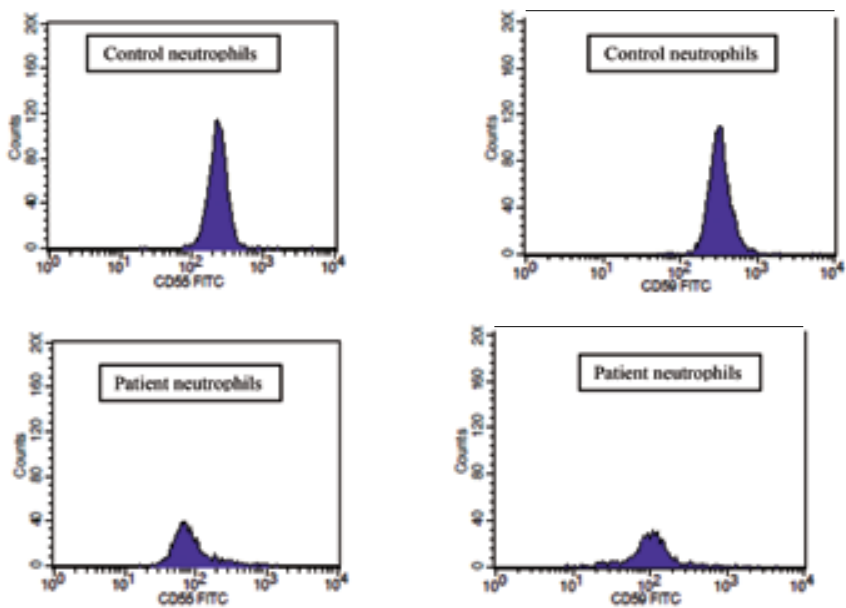

Figure 1b. Diminished expression of CD55 and CD59 on patient neutrophils.

antithrombin III antigens were all within the reference range. Flow cytometry analysis showed diminished expression of CD59 and CD55 in the neutrophils and erythrocytes in the absence of a discrete clone (Figures $1 \mathrm{a}$ and $1 \mathrm{~b}$ ). The expressions of CD59 and CD55 on lymphocytes were normal. Informed consent was obtained.

$\mathrm{PNH}$ is characterized by the deficiency of glycosyl phosphatidylinositol-anchored proteins CD55 and CD59, leading to increased susceptibility to complement-mediated lysis of erythrocytes, leukocytes, and platelets. Diminished expression of CD55 and/or CD59 was previously reported in SLE patients with lymphopenia $[4,5]$ and hemolytic anemia $[3,6]$. Antibodies against lymphocytes are claimed to cause lymphopenia via mechanisms including antibody-dependent cellular cytotoxicity, opsonization, surface receptor blockage, or apoptosis [5]. However, diminished expression of CD55 and/or CD59 leading to enhanced susceptibility to complement-mediated lysis might also have caused lymphopenia. Our patient had neutropenia with a normal lymphocyte count and did not seem to have PNH as she had no discrete PNH clone, despite diminished expression of CD59 on erythrocytes and CD55-CD59 expression on neutrophils. We think that the diminished expression of complement regulatory proteins in the presented patient might be secondary to SLE-derived autoantibodies, which might lead to complement-mediated cell (neutrophil) lysis and might have contributed to the development of neutropenia. Our patient also had concomitant pulmonary embolism. To the best of our knowledge, diminished expression of CD55 and/or CD59 was not reported before in SLE patients with isolated neutropenia in the absence of $\mathrm{PNH}$.

\section{Conflict of Interest Statement}

The authors of this paper have no conflicts of interest, including specific financial interests, relationships, and/ or affiliations relevant to the subject matter or materials included.

Key Words: SLE, CD55, CD59, PNH

Anahtar Sözcükler: SLE, CD55, CD59, PNH

\section{References}

1. Gupta A, Al Fulaij R, Gupta RK, Gupta G, Marouf R. Development of paroxysmal nocturnal haemoglobinuria in systemic lupus erythematosus: an unusual cause of portal vein thrombosis. Lupus 2009;18:743-746.

2. Tomizuka H, Hatake K, Kitagawa S, Yamashita K, Arai H, Miura Y. Portal vein thrombosis in paroxysmal nocturnal haemoglobinuria. Acta Haematol 1999;101:149-152.

3. Ruiz-Delgado GJ, Vázquez-Garza E, Méndez-Ramírez N, Gómez-Almaguer D. Abnormalities in the expression of CD55 and CD59 surface molecules on peripheral blood cells are not specific to paroxysmal nocturnal hemoglobinuria. Hematology 2009; 14:33-37.

4. García-Valladares I, Atisha-Fregoso Y, Richaud-Patin Y, JakezOcampo J, Soto-Vega E, Elías-López D, Carrillo-Maravilla E, Cabiedes J, Ruiz-Argüelles A, Llorente L. Diminished expression of complement regulatory proteins (CD55 and CD59) in lymphocytes from systemic lupus erythematosus patients with lymphopenia. Lupus 2006;15:600-605.

5. Ruiz-Argüelles A, Llorente L. The role of complement regulatory proteins (CD55 and CD59) in the pathogenesis of autoimmune hemocytopenias. Autoimmun Rev 2007;6:155-161.

6. Richaud-Patin Y, Pérez-Romano B, Carrillo-Maravilla E, Rodriguez AB, Simon AJ, Cabiedes J, Jakez-Ocampo J, Llorente L, Ruiz-Argüelles A. Deficiency of red cell bound CD55 and CD59 in patients with systemic lupus erythematosus. Immunol Lett 2003;88:95-99. 